\title{
Effect of Soaking/Oven- Drying on Mechanical and Physical Properties of Birch (Befula spp.) Plywood
}

\section{Utjecaj namakanja i sušenja u sušioniku na mehanička i fizička svojstva furnirske ploče od brezovine (Betula spp.)}

Original scientific paper $\bullet$ Izvorni znanstveni rad Received-prispjelo: 12. 9. 2019.

Accepted-prihvaćeno: 14. 1. 2021.

UDK: $630 * 832.282 .6 ; 630 * 282.7$

https://doi.org/10.5552/drvind.2021.1946

(C) 2021 by the author(s). Licensee Faculty of Forestry and Wood Technology, University of Zagreb. This article is an open access article distributed under the terms and conditions of the

Creative Commons Attribution (CC BY) license.

\begin{abstract}
The objective of this study was to explore some of the physical and mechanical properties of 9-layer birch (Betula spp.) plywood with the addition of phenol-formaldehyde glue, in cases in which the cutting edges of the samples are coated with the damp-proof mastic Fibergum, and in case in which they remain unprocessed (uncoated), following a total of ten cycles of soaking/oven-drying. The properties to be determined were the bending strength (BS), modulus of elasticity in bending (MOE), thickness swelling (TS) and restore dimensions (RD), which were tested according to the European standards (EN). A linear-fractional equation and linear relationship were used for the approximation of any change in the physical and mechanical properties of the samples depending upon the number of soaking/oven-drying cycles. It was shown that the values of the properties investigated were most affected by the first soaking and drying cycle. Thereafter, BS and MOE levels decreased smoothly at a low rate, but the values of TS became stabilised. The BS and MOE values for the wet samples with coated cutting edges were higher than when they were uncoated, as the moisture levels in the former case were lower. After the first soaking of the samples with coated cutting edges, the retention values were as follows: BS at $52.8 \%$ and 66.7 $\%$ for the major and minor axes, respectively, with the same applying to MOE at $61.9 \%$ and $64.2 \%$, while TS was at $105.2 \%$. To clarify the phenomenon that causes a decrease of the properties, the face plies and edge structures of the initial dry samples and of the samples after the first, second and ninth soaking/oven-drying cycles were studied using the X-Ray technique.
\end{abstract}

Keywords: plywood; bending strength; modulus of elasticity; thickness swelling; restore dimensions; moisture content; X-Ray technique

SAŽETAK • Cilj ovog istraživanja bio je odrediti neka fizička i mehanička svojstva furnirske ploče od brezovine (Betula spp.) izrađene od devet slojeva furnira i uz dodatak fenol-formaldehidnog ljepila. Uzorci čiji su rubovi premazani za vlagu nepropusnim premazom Fibregum $i$ uzorci s nepremazanim rubovima namakani su i sušeni $u$ sušioniku tijekom deset ciklusa. Prema europskim standardima, ispitivana su ova svojstva ploče: čvrstoća na savijanje, modul elastičnosti, debljinsko bubrenje i vraćanje dimenzija uzoraka. Za aproksimaciju promjena fizičkih i mehaničkih svojstava uzoraka ovisno o broju ciklusa namakanja i sušenja u sušioniku primijenjeni su linearna frakcijska jednadžba i linearni odnos. Utvrđeno je da je na vrijednost ispitivanih svojstava najviše utjecao prvi

\footnotetext{
Authors are researchers at Estonian University of Life Sciences, Institute of Forestry and Rural Engineering, Tartu, Estonia.

${ }^{2}$ Author is researcher at Tallinn University of Technology, Tartu College, School of Engineering, Tartu, Estonia.

Author is researcher at Estonian University of Life Sciences, Institute of Technology, Tartu, Estonia.
} 
ciklus namakanja i sušenja. Nakon tog ciklusa namakanja i sušenja čvrstoća na savijanje i modul elastičnosti polako su se smanjivali, dok su se vrijednosti debljinskog bubrenja stabilizirale. Vrijednosti čvrstoće na savijanje i modula elastičnosti vlažnih uzoraka s premazanim rubovima bile su veće nego za uzorke s nepremazanim rubovima zbog manjeg sadržaja vode u uzorcima premazanih rubova. Nakon prvog namakanja uzoraka s premazanim rubovima zadržane su ove vrijednosti: čvrstoća na savijanje na 52,8 i 66,7 \% te modul elastičnosti na 61,9 i 64,2 $\%$ za glavnu odnosno sporednu os, dok je debljinsko bubrenje iznosilo 105,2\%. Za objašnjenje fenomena smanjenja ispitivanih svojstava, lica slojeva furnira i rubne strukture uzoraka nakon prvoga, drugoga i devetog ciklusa namakanja i sušenja u sušioniku primijenjena je rendgenska metoda.

Ključne rijječi: furnirska ploča; čvrstoća na svijanje; modul elastičnosti; debljinsko bubrenje; vraćanje dimenzija; sadržaj vode; rendgenska metoda

\section{INTRODUCTION}

\section{UVOD}

Birch (Betula spp.) is found in Eurasia and forms a second widespread tree species in Estonia, reaching $29 \%$ of the total land space across the country (Estonian is a country of forests - Statistics). Birch is considered a form of hardwood and has good mechanical properties resulting in an increasing demand when it comes to its use in products such as lumber, sawn timber and plywood. Plywood is made by bonding together several hardwood plies (mostly for indoor products) or softwood plies (mostly for outdoor products) (Dieste $e t$ al., 2008; Cosereanu et al., 2010; Lipinskis et al., 2011; Zalemanis et al., 2018). The mechanical properties of hardwood are better when they are compared to those of softwood, which makes hardwood a better research object. In more recent times, Finnish birch plywood has been used outdoors: for concrete shuttering, scaffolding, vessels, vans, and so on (Finnish Forest, 2002, Metsä Wood). There are a good many important factors that affect the physical properties of plywood (such as moisture, thickness swelling and density) and its mechanical properties (strength characteristics), such as: trees species, wood density, slope of grains, shakes, checks, number of plies, type of adhesives, thicknesses of plies and the technological parameters involved in the manufacturing process.

Veneer and plywood (including block board) are the dominating wood-based panel types, which accounted for $42 \%\left(174\right.$ million $\left.\mathrm{m}^{3}\right)$ of all wood-based panel production in 2016 (UN 2016). According to different estimates, the global market for plywood is expected to keep growing in the near future (at a compound annual growth rate CAGR of $6.0 \%, 7.8 \%$ and $9.7 \%$ in 2018-2028 (Plywood Market Reports, 2018), 2017-2022 (Plywood Manufacturing, 2018) and 20192023 (Plywood Market, 2019) respectively.

As a wood-based material, the physical and mechanical properties of plywood are affected by moisture. Plywood is a highly valued construction material, one which is used more widely than other wood-based panels in conditions that involve outdoor exposure. To be able to determine the average moisture of wood and plywood samples, a continuous moisture measurement (CMM) set-up was developed (Van den Bulcke et al., 2009). According to the data gained from a CMM setup, further analysis was varied out on the relationship between weather data and the number of days with an average $M C$ that were higher than $20 \%$ or $25 \%$ (Van den Bulcke et al., 2011). With a similar set-up, an adapted electrical moisture measurement method was introduced by Li et al., (2013) to measure internal moisture levels in plywood.

In practice, weathering conditions with alternating soaking and drying cycles can reduce the mechanical properties of plywood. Li et al., (2016) studied moisture behaviour and structural changes in different layers of plywood specimens that had been exposed to outdoor weather conditions for approximately one year. It became apparent that moisture distribution in plywood was not homogeneous in outdoor conditions. In some plywood types, the second layer can accumulate a significant amount of rain, and long rainy periods and cloudy weather can cause the inner plywood layers to retain high moisture levels. The glue line between the plies was not ruptured after one year of outdoor exposure. River (1994) studied outdoor aging (at a point between 7 to 12 years) in wood-based panels (including one panel of 5-ply, Douglas fir, and marine graded commercial plywood) and its correlation with accelerated aging in the laboratory. The plywood panel that was the subject of the study belonged to a group of panels with the highest levels of resistance to outdoor exposure, managing to retain $99.6 \%$ and $48.6 \%$ of their initial bending strength $(B S)$ (modulus of rupture, $M O R)$ after one year and ten years, respectively. Significant correlations (Pearson's and Spearman's correlation coefficients $>0.90$ ) were found between $M O R$ after cyclic boil-dry $(B D)$ aging and $M O R$ after outdoor aging (River, 1994).

For companies that are involved in producing plywood, quality control is essential for the commercialization of this type of wood. As it has already been established that a wood product will have insufficient levels of strength and dimensional stability during the course of changing moisture levels, it is reasonable to investigate some of the mechanical and physical properties of plywood depending upon the number of soaking/oven-drying cycles.

The objective of this paper was to study changes in $B S, M O E$, and $T S$ after ten soaking/oven-drying cycles, with the investigation involving the cutting forehead and the facet edges of the samples being coated with the damp-proof mastic Fibergum, see Master's thesis (Kruus, 2016). In the earliest studies, the cutting edges remained unprocessed (uncoated) - see Master's theses (Kasepuu, 2014 and Sooru, 2015). 
Approximated experimental data used a linearfractional expression for the investigated $B S$, and $M O E$, and the linear relationship for $T S$ and $R D$ depending upon the number of soaking/oven-drying cycles. Also, the statistically significant $(p<0.05)$ coefficient of variation $(\mathrm{CV})$ was estimated and calculated in percentages for average values according to EVS EN 326-1:2002. The effects of soaking/oven-drying have been clarified in terms on the face plies and edge structure of the samples evaluated by means of the X-Ray technique.

\section{MATERIALS AND METHODS 2. MATERIJALI I METODE}

Three 9-layer commercial uncoated Wisa birch (Betula spp. grown in south-eastern Estonia) plywood moisture-proof panels with nominal dimensions of $3000 \mathrm{~mm} \times 1500 \mathrm{~mm} \times 12 \mathrm{~mm}$ were produced by UPM-Kymmene, Otepää, Estonia. Engineered hardwood plywood panels were commonly glued together with phenol-formaldehyde resin (PF) as the selected wood adhesive (Manufacturing Process of Veneer and Plywood). The dimensions of each test sample (290 $\mathrm{mm} \times 50 \mathrm{~mm} \times 12 \mathrm{~mm}$ ) for $B S$ and $M O E$ were marked out from larger panels and were cut out in the parallel direction (II - major axis) and perpendicular direction ( $\mathrm{T}$ - minor axis) to the face plie grain. Experiments were carried out with eleven series (with a minimum of twelve samples in a series), the first of them (dry) added also to the calculations for soaked samples. The cutting forehead and the facet edges of the test samples, as extracted from the two panels, were coated with the damp-proof mastic Fibergum, and those from the third panel remained unprocessed (uncoated). All samples were divided into two groups. One group of samples was tested in a wet (soaked) state, while the second group was tested in a dried state. The test samples were placed in a tank of room temperature water $(22 \pm 2){ }^{\circ} \mathrm{C}$ for a period of 24 hours. The samples were dried (over 48 hours) in a ventilated drying box at $(65 \pm 2)^{\circ} \mathrm{C}$ and after that, they were conditioned in a climatic chamber at a relative humidity level of $(65 \pm 5) \%$ at $(21 \pm 2){ }^{\circ} \mathrm{C}$. The dimensions and weight of the bending test samples were measured immediately after they were taken out of the water tank or the climatic chamber, in order to determine their $T S, R D$ and $M C$ (using the weighing method) according to the EVS-EN 317: 2000 and EVS-EN 322: 2002 standards. The dimensions of the samples were measured using a digital calliper with an accuracy of $0.01 \mathrm{~mm}$ and a screw gauge (Mitutoyo 293805) with an accuracy of $0.001 \mathrm{~mm}$ (EVS-EN 325: 2002); the weight of the samples was measured by means of an electrical balance, a Kern PLB 1000-2 with an accuracy of $0.01 \mathrm{~g}$ and samples were tested immediately. The computer-controlled mechanically-actuated universal testing machine, an Instron 3369, was also used. Deflection values for a determination of the modulus of elasticity were measured by means of an optical gauge (Advanced Video Extensometer 2663821). Samples for determining $B S$ and $M O E$ were test- ed following the three-point flatwise bending test in accordance with the EVS-EN 310: 2002 standard. A load was applied at a constant rate so that failure occurred in $(60 \pm 30)$ seconds.

In order to be able to evaluate $B S$ and $M O E$ at static flexion in the directions of the II-major axis and T-minor axis in relation to the grain on the face plies, the process formulated by (Sooru et al., 2015) was realised and calculated according to the EVS-EN 310: 2002 standard. Calculation for the coefficient of the variation of the measurements was carried out according to the EVS-EN 326-1: 2002 standard.

Dimensional stability (swelling in thickness) was determined prior to the bending test in the middle zone of the samples (for more details see Figure $1 b$ in Sooru et al., 2015).

The following linear-fractional function (equilateral hyperbola) was used to approximate the experimental data obtained for the properties investigated, depending upon the number of soaking/oven-drying cycles (Lille et al., 2013 and Sooru et al., 2015)

$$
Y(x)=\left(\mathrm{d}\left(Y_{\mathrm{i}}-Y_{\mathrm{f}}\right) /(c x+d)\right)+Y_{\mathrm{f}},
$$

in this $Y_{\mathrm{i}}, Y_{\mathrm{f}}$ are the calculated initial $(x=0)$ and final values $(x=\infty)$ of the properties investigated, while $x$ is the number of cycles, and $c$ and $d$ are constants.

The initial and final values of the properties and constants should be determined so that the measured experimental data are approximated in the best possible way by minimising the square of error (least squares regression). This problem was solved by using the Mathcad 15.0 programme with the regression function $\operatorname{genfit}(v x, v y, v g, F)$. The following assumptions were made for the mathematical expressions (the values of $B S$ and $M O E$ versus the number of soaking/oven-drying cycles): the approximation curve, first, cuts ordinate; and second, making it possible to determine the limit values, in which $B S$ and $M O E$ stabilise.

The formula (1) also makes it possible to predict, to a certain extent, the mechanical and physical properties of the samples when their values are known after the application of a small number of soaking/ovendrying cycles (between two and three). The relationship between $T S$ and $R D$ depending upon the number of cycles is approximated in the best way possible by minimising the square of error, by using the software, MS Excel, with the results being reached by means of regression analysis function found by the programme. The YXLON FF35 CT computed tomography system was applied for an X-Ray investigation of the structure of plywood.

\section{RESULTS AND DISCUSSION} 3. REZULTATI I RASPRAVA

Following a degree of room temperature water absorption $(22 \pm 2){ }^{\circ} \mathrm{C}$ by the test samples after a soaking time of 24 hours, the average moisture was about $(25.3 \pm 1.7) \%$ and $(40.0 \pm 4.0) \%$ for the coated and unprocessed cutting edges, respectively. Coating the cutting edges of the test samples inhibited water ab- 
sorption considerably. After drying, the average moisture was $(7.7 \pm 1.8) \%$.

The mean values obtained for one cycle of $B S$ and $M O E$ in the directions of the II-major axis and Tminor axis are presented in Figure 1, for oven-dry (7.7 $\pm 1.8) \%$ and wet $(25.3 \pm 1.7) \%$, where the cutting edges are coated with mastic, and in Figure 2, for wet $(40.0 \pm 4.0) \%$, (for oven-dry, see more in Sooru et al.,
2015), where the cutting edges have remained unprocessed.

All mean values in the experimental data were approximated by means of Eq. 1 and are presented as curves of the calculated values of the properties investigated and their constants. Also, the coefficient of variation $(\mathrm{CV})$ for the mean values was calculated in percentages.
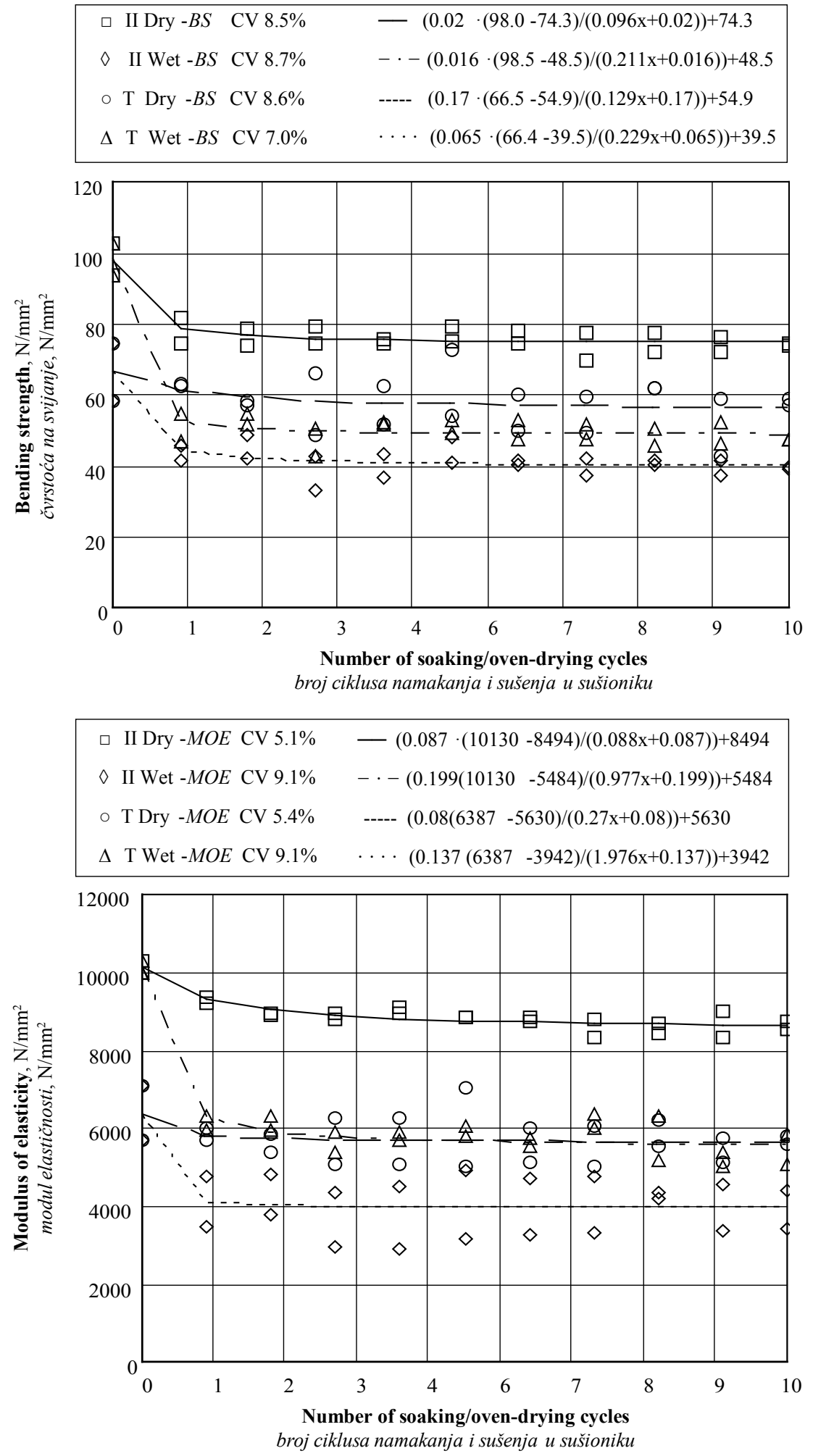

Figure 1 Dependence of $B S$ (marked as $f_{\mathrm{m}}$ ) and $M O E$ (marked as $E_{\mathrm{m}}$ ) on the number of soaking/oven-drying cycles, mean values from experimental data with $\mathrm{CV}$ and curves of approximation

Slika 1. Ovisnost čvrstoće na savijanje i modula elastičnosti o broju ciklusa namakanja i sušenja u sušioniku, srednje vrijednosti iz eksperimentalnih podataka s koeficijentima varijacije i aproksimacijskim krivuljama 

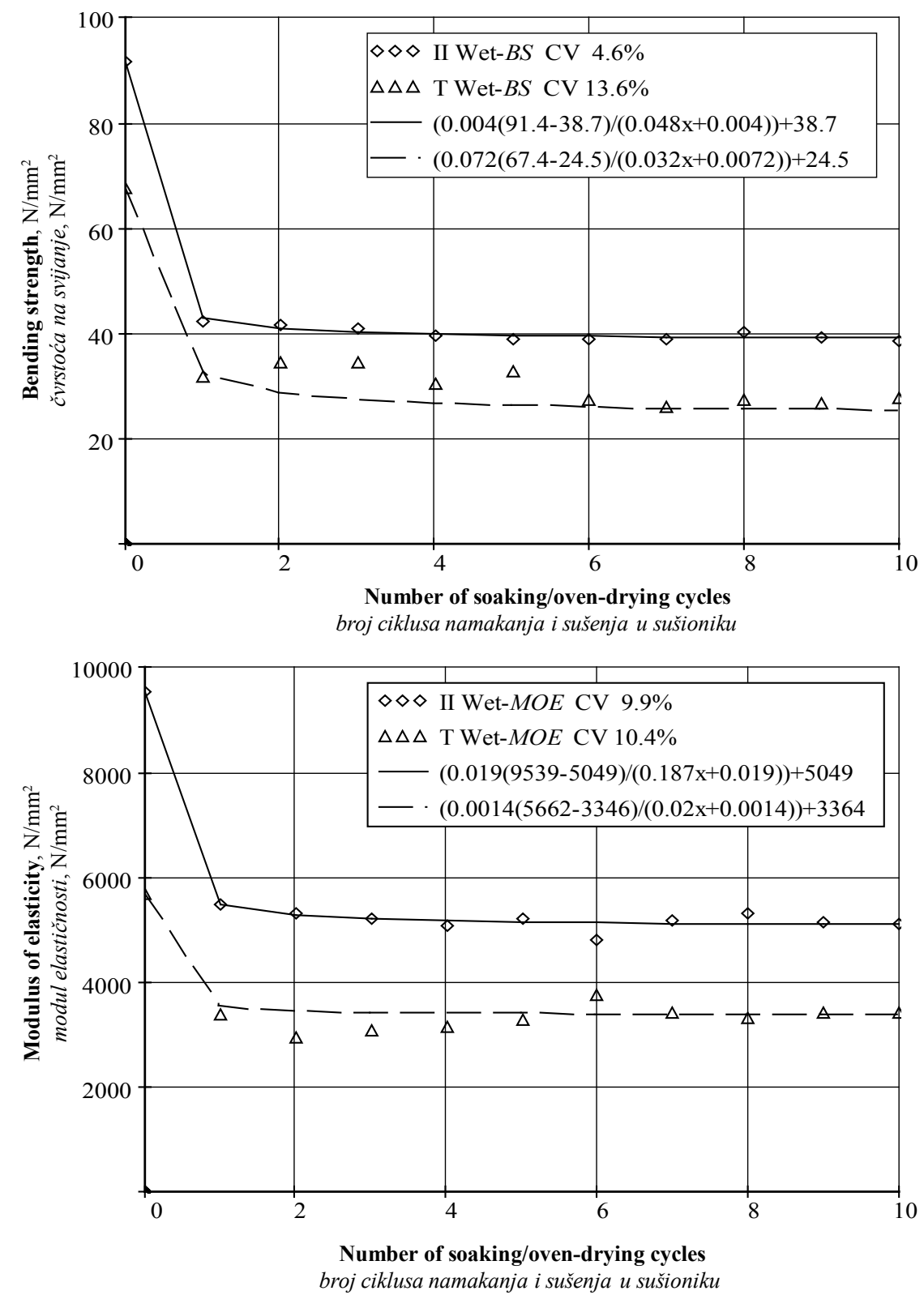

Figure 2 Dependence of $B S$ and $M O E$ on the number of soaking/oven-drying cycles, mean values from experimental data and curves of approximation

Slika 2. Ovisnost čvrstoće na savijanje i modula elastičnosti o broju ciklusa namakanja i sušenja u sušioniku, srednje vrijednosti iz eksperimentalnih podataka i aproksimacijske krivulje

The experimental data for all the properties studied tended to fluctuate to a moderate extent as the plywood had been produced from heterogeneous wood material and the plies had natural flaws and knots.

Consequently, after 24 hours of soaking, when the cutting edges were coated and water absorption through them was blocked, the moisture $(25.3 \pm 1.7) \%$ was about $15 \%$ lower than in the samples with unprocessed cutting edges $(40.0 \pm 4.0) \%$. On the other hand, considering that the barrier, which had been provided by the glue used for the bonding of the plies, inhibits the absorption of water through the faces, moisture levels in the panels with significantly larger dimensions was lower than in the samples with unprocessed (uncoated) cutting edges. It was shown that the direction of the face grain direction plays an important role in some properties of structural plywood panels. The $B S$ and $M O E$ values differed significantly depending upon whether they were measured in parallel or perpendicular to the samples. The determined values of the properties investigated for the samples of the T-minor axis fluctuated more than those for the samples of the IImajor axis. For the parallel samples, the direction of the experimental load in relation to the face grain was tangential (T), while the direction of the internal load in relation to the face grain was longitudinal (L); for the perpendicular samples, the situation was the opposite. The tensile strength in the $\mathrm{T}$ direction of European beech wood was many times lower than in the L direction. It can be seen that the proposed Eq. 1 approximated the experimental data quite satisfactorily. It should be noted that the values for the calculated percentages are taken from the approximation curves and are presented in Table 1. 


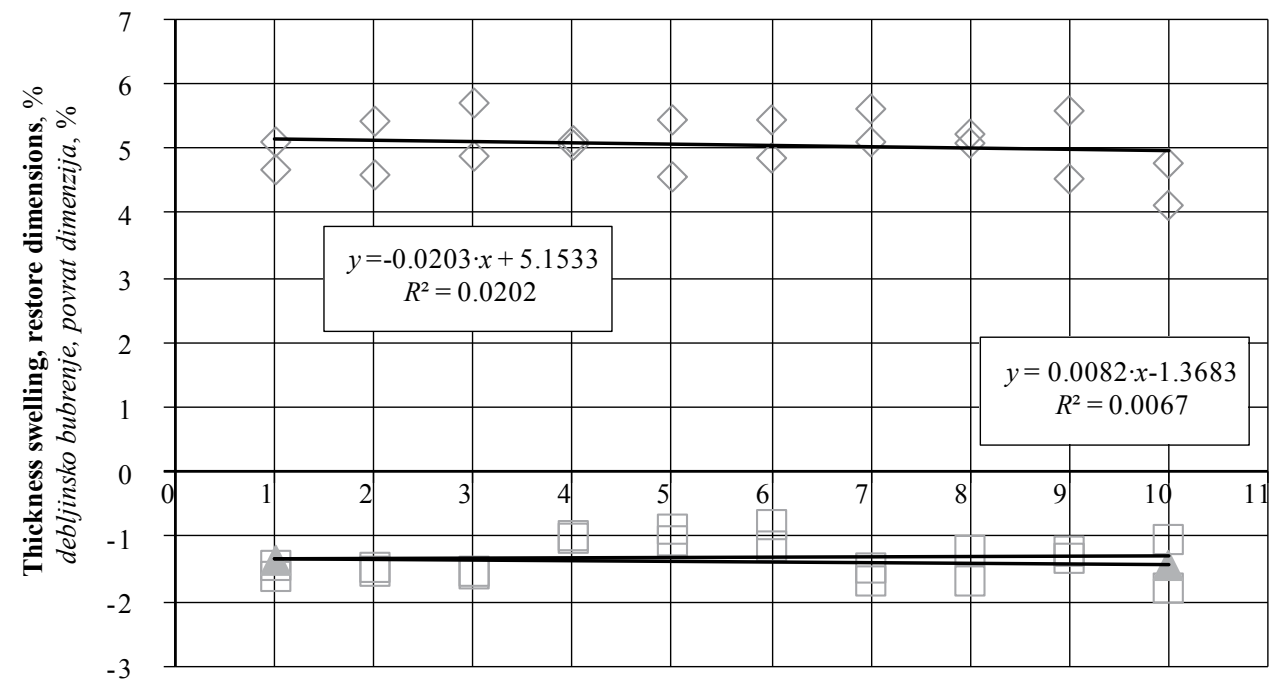

Number of soaking/oven-drying cycles

broj ciklusa namakanja i sušenja u sušioniku

Figure 3 Dependence of Wet-TS and Dry-TS for plywood on the number of soaking/oven-drying cycles: mean values for trend lines are at $5.15 \%$ and $-1.37 \%$, respectively

Slika 3. Ovisnost mokroga i suhoga debljinskog bubrenja furnirske ploče o broju ciklusa namakanja i sušenja u sušioniku: srednje vrijednosti za linije trenda su 5,15\% odnosno $-1,37 \%$

The linear relations between mean values for one cycle of $T S$ and $R D$, depending upon the number of soaking/oven-drying cycles are presented in Figure 3.

The $T S$ was $5.2 \%$ and $7.1 \%$ at a moisture of about $(25.3 \pm 1.7) \%$ and $(40.0 \pm 4.0) \%$, respectively, while the thickness $R D$ in the dried samples at a moisture of $(7.7 \pm 1.8) \%$ was $98.6 \%$. The reduction in $T S$ may indicate a volume decrease of the face plies due to plastic deformation during the first soaking period and also to manufacturing residues (including particles and dust) in the plywood, which were washed off during the soaking cycle.

The $T S$ for the plywood did not change significantly after the first soaking/oven-drying cycles $(7.7 \pm$ $1.8) \%$. This phenomenon has been noted in the case of wood. Swelling in wood, which is also similar to swelling in plie as a wood product, takes place below the fibre saturation point (FSP) (about $30 \%$ ), at which the

Table 1 Mean values for $B S, M O E$, $T S$ and $R D$ for dry and moist test samples and residual values of wet samples versus dry samples

Tablica 1. Srednje vrijednosti čvrstoće na savijanje, modula elastičnosti, debljinskog bubrenja i vraćanja dimenzija za suhe i vlažne uzorke te rezidualne vrijednosti vlažnih uzoraka u odnosu prema suhima

\begin{tabular}{|c|c|c|c|c|c|c|c|c|}
\hline & \multirow{2}{*}{\multicolumn{2}{|c|}{$\begin{array}{c}\text { Dried / Sušeni, } \% \\
7.7 \pm 1.8\end{array}$}} & \multicolumn{4}{|c|}{ Soaked / Namakani, \% } \\
\hline & & & & & \multicolumn{2}{|c|}{$25.3 \pm 1.7$} & \multicolumn{2}{|c|}{$40.0 \pm 4.0$} \\
\hline \multirow{2}{*}{\multicolumn{3}{|c|}{$\begin{array}{l}\text { Moisture, axis / Sadržaj vode, osi } \\
\text { Properties investigated, retention values } \\
\text { Istraživana svojstva, zadržane vrijednosti }\end{array}$}} & & \multicolumn{2}{|c|}{ Axis } & \multirow[b]{2}{*}{$\begin{array}{l}\text { Major } \\
\text { II }\end{array}$} & \multirow[b]{2}{*}{$\begin{array}{c}\text { Minor } \\
\mathrm{T}\end{array}$} \\
\hline & & & $\begin{array}{l}\text { Major } \\
\text { II }\end{array}$ & $\begin{array}{c}\text { Minor } \\
\mathrm{T}\end{array}$ & $\begin{array}{l}\text { Major } \\
\text { II }\end{array}$ & $\begin{array}{l}\text { Minor } \\
\mathrm{T}\end{array}$ & & \\
\hline \multicolumn{3}{|c|}{ Mean values / Srednje vrijednosti, N/mm ${ }^{2}$} & & & & & & \\
\hline \multirow[t]{2}{*}{$\begin{array}{l}\text { Bending strength } \\
\text { Čvrstoća na savijanje }\end{array}$} & \multicolumn{2}{|c|}{ initial, $f_{\mathrm{mi}}$} & 98.0 & 66.5 & 98.5 & 66,4 & 91.4 & 67.4 \\
\hline & \multicolumn{2}{|c|}{ final, $f_{\mathrm{mj}}$} & 74.3 & 54.9 & 48.5 & 39.5 & 38.7 & 24.5 \\
\hline \multirow[t]{2}{*}{$\begin{array}{l}\text { Modulus of elasticity } \\
\text { Modul elastičnosti }\end{array}$} & \multicolumn{2}{|c|}{ initial, $E_{\mathrm{mi}}$} & 10130 & 6387 & 10130 & 6387 & 9539 & 5662 \\
\hline & \multicolumn{2}{|c|}{ final, $E_{\mathrm{mf}}$} & 8494 & 5630 & 5484 & 3942 & 5049 & 3364 \\
\hline \multicolumn{9}{|c|}{$\begin{array}{l}\text { Mean residual values vs those obtained from initial } \\
\text { dry samples, \% } \\
\text { Srednje rezidualne vrijednosti u odnosu prema onima } \\
\text { dobivenim za početne suhe uzorke, \% } \\
\end{array}$} \\
\hline \multirow{2}{*}{$\begin{array}{l}\text { After first cycle } \\
\text { Nakon prvog ciklusa }\end{array}$} & $B S$ & $f_{\mathrm{ml}} / f_{\mathrm{mi}}$ & 80.0 & 92.5 & 52.8 & 66.7 & 46.8 & 48.0 \\
\hline & $M O E$ & $E_{\mathrm{ml}} / E_{\mathrm{mi}}$ & 91.9 & 90.9 & 61.9 & 64.2 & 57.3 & 62.1 \\
\hline \multirow{2}{*}{$\begin{array}{l}\text { Final } \\
\text { Završno }\end{array}$} & $B S$ & $f_{\mathrm{mj}} / f_{\mathrm{mi}}$ & 75.8 & 82.6 & 49.2 & 59.5 & 42.3 & 36.4 \\
\hline & $M O E$ & $E_{\mathrm{mj}} / E_{\mathrm{mi}}$ & 83.8 & 88.1 & 54.1 & 61.7 & 53.9 & 35.3 \\
\hline \multirow{2}{*}{\multicolumn{2}{|c|}{$\begin{array}{l}\text { Thickness swelling / Debljinsko bubrenje } \\
\text { Restore dimension/ Povrat dimenzija }\end{array}$}} & \multirow{2}{*}{$\%$} & & & \multicolumn{2}{|c|}{5.2} & \multicolumn{2}{|c|}{7.1} \\
\hline & & & & & & & & \\
\hline
\end{tabular}


Kask, Lille, Kiviste, Kruus, Lääne: Effect of Soaking/Oven-Drying on Mechanical and...

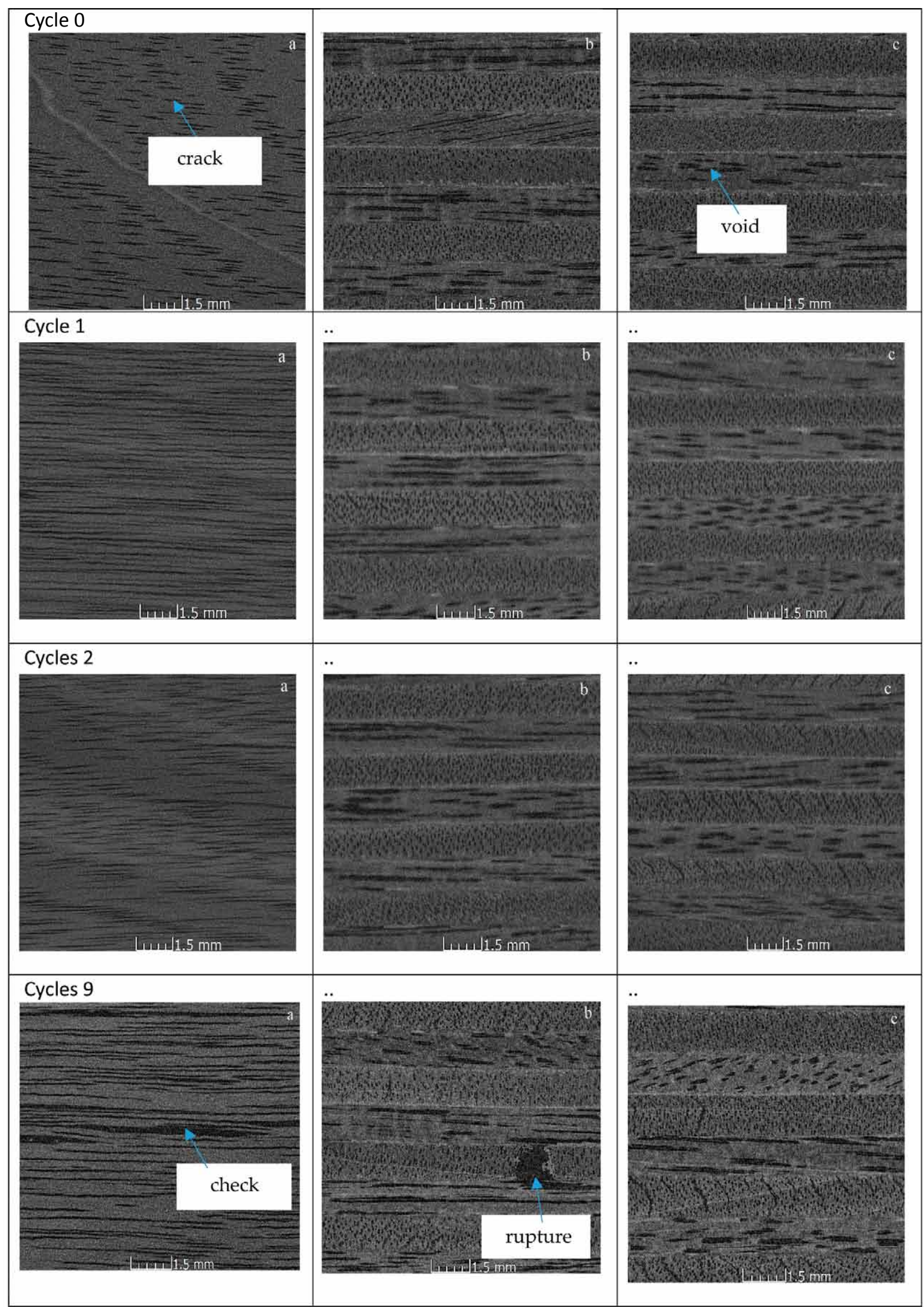

Figure 4 X-Ray images of texture of samples: a) face plies; b) middle edge in parallel with II-axis; c) in parallel with T-axis; purveyance dry ( 0 cycle), and after the first, second and ninth soaking/oven-drying cycle

Slika 4. Rendgenske slike teksture uzoraka: a) slojevi lica; b) srednji rub paralelno s osi II; c) paralelno s osi T; suho (0 ciklusa), nakon prvoga, drugoga i devetog ciklusa namakanja i sušenja u sušioniku 
total amount of water is present within the cell wall (Hiziroglu, 2017). Regardless of the number of soaking/oven-drying cycles, the dimensions of the plywood do not change. The $B S$ and $M O E$ for samples generally increase when the moisture decreases below the FSP.

The X-Ray images of the structure of the face plies and edge of the dry samples, both at the initial time point and after the first, second and ninth soaking/ oven-drying cycles are presented in Figure 4.

Manufactured plywood, especially face plies, contain cracks, which have developed after peeling from wetted logs and consecutive drying (Figure 4a-0). Numerous new cracks appeared in the face plies after the first soaking and oven-drying cycle (Figure 4a-1), which in turn decreased the strength characteristics of the samples. The main factor for the formation of new cracks may be the following: moisture accumulation in the face plies was higher due to the direct contact with water of the outer surface and the surfaces of the existing cracks. This, in combination with the wood species, causes swelling and consecutive plastic deformations, as less swollen core plies (adhesive layers reduce moisture transport across plywood) served to prevent their free elongation and hence the development of compressive stresses during the early soaking period. In the oven-drying period, moisture is first decreased (desorption) in the most swollen face plies, but at the same time, their free shrinkage is resisted by the less swollen core plies. Thanks to this, and due to the development of tensile stresses, new cracks are formed in the face plies when these stresses exceed their corresponding strengths.

The swell and shrinkage of core plies is less small, because adhesive glue lines allow reduced moisture transport across the plywood. As the core plies do not have any resistance to shrinkage during oven/drying, they show no visually discernible changes (Figure $4 \mathrm{~b}-1$ and $4 \mathrm{c}-1)$.

After the next soaking period, the network of cracks in the face plies eliminates free swelling and in the oven/drying period some of the cracks only expand or extend (Figure 4a-2). At the same time, no noticeable changes were found in the core plies (Figure 4b-2 and $4 c-2)$. This may be the reason for the stabilisation of the properties of the plywood studied. After the ninth soaking/oven-drying cycle, the cracks in the face plies have further expanded (Figure 4a-9) or have extended, and some of the micro fibrils in the core plies and adhesive glue line have ruptured (Figure 4b-9 and 4c-9).

\section{CONCLUSIONS}

\section{ZAKLJUČAK}

The mechanical and physical properties of 9-layered birch plywood after soaking/oven-drying cycles were investigated according to European standards. Experiments were carried out with eleven series, with a minimum of twelve samples in a series.

After the first soaking at a moisture level of (25.3 $\pm 1.7) \%$, the retention values were as follows: $B S$ at
$52.8 \%$ and $66.7 \%$ for the major and minor axes, respectively, with the same applying to $M O E$ at $61.9 \%$ and $64.2 \%$, while $T S$ was at $105.2 \%$. At a moisture of $(40.0 \pm 4.0) \%$, the retention values were as follows: $B S$ at $46.8 \%$ and $48.0 \%$ for the major and minor axes respectively, with the same applying to $M O E$ at $57.3 \%$ and $62.1 \%$, and with TS at $107.1 \%$.

After the first soaking and drying test (with a moisture of $(7.7 \pm 1.8) \%)$, the retention values were as follows: $B S$ at $80.0 \%$ and $92.5 \%$ for the major and minor axes, respectively, with the same applying to $M O E$ at $91.9 \%$ and $90.9 \%$, and with $R D$ at a thickness of $98.6 \%$.

The proposed analytical function satisfactorily approximated the $B S$ and $M O E$ experimental data, depending upon the number of soaking/oven-drying cycles.

The results of the X-Ray investigations showed that the causes of abrupt change in the properties of the plywood samples were rapid water sorption-desorption and the related swelling-shrinkage of the face plies on the plywood in restrained elongation conditions.

The analysis, as presented here, is limited to data obtained from the aforementioned experiments.

\section{Acknowledgements - Zahvala}

The X-Ray investigations for the current study were supported by the European Regional Fund, project No. 2014-2020.4.01.16-0183, Smart Industry Centre (SmartIC).

\section{REFERENCES}

5. LITERATURA

1. Dieste, A.; Krause, A.; Bollmus; S, Militz, H., 2008: Physical and mechanical properties of plywood produced with 1.3-dimethylol-4.5-dihydroxyethyleneurea (DMDHEU)-modified veneers of Betula sp. and Fagus sylvatica. Holz als Roh- und Werkstoff, 66 (4): 281-287. https://doi.org/10.1007/s00107-008-0247-3.

2. Cosereanu, C.; Lica, D.; Curtu, I.; Lunguleasa, A.; Cismaru, I.; Brenci, L.; Fotin, A., 2010: Mechanical Testing of Beech Veneer Sandwich Composites. In: Proceeding of $7^{\text {th }}$ Internation DAAAM Baltic Conference. Industrial Engineering, Tallinn, Estonia.

3. Hiziroglu, S., 2017: Dimensional Changes in Wood. Oklahoma Cooperative Extension Service. http://pods. dasnr.okstate.edu/docushare/dsweb/Get/Rendition-7237/ NREM-5009web.pdf.

4. Kasepuu, K., 2014: Effect of plywood soaking and drying cycles on mechanical and physical properties. MSc Thesis, Estonian University of Life Sciences, Tartu, Estonia (in Estonian). https://dspace.emu.ee/xmlui/bitstream/ handle/10492/1751/Kaido_Kasepuu_MA2014.pdf? sequence $=3 \&$ isAllowed $=y$.

5. Kruus, S., 2016: Changes in physical and mechanical properties of moisture resistant birch plywood after soaking and oven-drying cycles. MSc Thesis, Estonian University of Life Sciences, Tartu, Estonia (in Estonian). https://dspace.emu.ee/xmlui/browse?type=author\&value $=$ Kruus $\% 2 \mathrm{C}+$ Silver.

6. Li, W. Z.; Van den Bulcke, J.; De Windt, I.; Van Loo, D.; Dierick, M.; Brabant, L.; Van Acker, J., 2013: Combining electrical resistance and 3-D X-ray computed tomogra- 
phy for moisture distribution measurements in wood products exposed in dynamic moisture conditions. Building and Environment, 67: 250-259.

https://doi.org/10.1016/j.buildenv.2013.05.026.

7. Li, W. Z.; Van den Bulcke, J.; De Windt, I.; Dhaene, J.; Van Acker, J., 2016: Moisture behavior and structural changes of plywood during outdoor exposure. European Journal of Wood and Wood Products, 74 (2): 211-221. https://doi.org/10.1007/s00107-015-0992-z.

8. Lille, H.; Kõo, J.; Ryabchikov, A.; Reitsnik, R.; Veinthal, R.; Mikli, V.; Sergejev, F., 2012: Investigation of residual stresses and some elastic properties of brush-plated gold and silver coatings. Key Engineering Materials, 527: 125-130. https://doi.org/10.4028/www.scientific.net/KEM. 527.125 .

9. Lipinskis, I.; Spulle, U., 2011: Research of mechanical properties of birch plywood with special veneer lay-up schemes. Drewno, 54 (185): 109-118.

10. Zalemanis, A.; Zudrags, K.; Japinš, G., 2018: Birch plywood sample tension and bending property investigation and validation in solidworks environment. In: Proceeding of $24^{\text {th }}$ International Scientific Conference Research for Rural Development, Jelgava, Latvia, 1: 103-110. https://doi.org/10.22616/rrd.24.2018.016.

11. River, B. H., 1994: Outdoor aging of wood panels and correlation with laboratory aging. Forest Products Journal, 44: 55-65.

12. Sooru, M., 2015: Variation in mechanical and physical properties of birch plywood after soaking/oven-drying cycles. MSc Thesis, Estonian University of Life Sciences, Tartu, Estonia (in Estonian). https://dspace.emu.ee/ xmlui/bitstream/handle/10492/2171/Marko_Sooru $2015 \mathrm{MA}$ AT_t\%c3\%a4istekst.pdf? sequence $=1$ \&isAllowed $=\mathrm{y}$.

13. Sooru, M.; Kasepuu, K.; Kask, R.; Lille, H., 2015: Impact of soaking/oven-drying cycles on the mechanical and physical properties of birch plywood. IOP Conference Series: Materials Science and Engineering, 96: 012075. https://iopscience.iop.org/article/10.1088/1757899X/96/1/012075/pdf.

14. Van den Bulcke, J.; Van Acker, J.; De Smet, J., 2009: An experimental setup for real-time continuous moisture measurements of plywood exposed to outdoor climate. Building and Environment, 44 (12): 2368-2377. https://doi.org/10.1016/j.buildenv.2009.03.021.

15. Van den Bulcke, J.; De Windt, I.; Defoirdt, N.; De Smet, J.; Van Acker, J., 2011: Moisture dynamics and fungal susceptibility of plywood. International Biodeterioration \& Biodegradation, 65 (5): 708-716. https://doi.org/10.1016/j.ibiod.2010.12.015.

16. ***Estonian Centre for Standardization, EVS EN 326-1, 2002: Puitplaadid. Proovivõtt, lõikamine ja kontroll. Osa 1: Proovivõtt, katsekehade lõikamine ja katsetulemuste väljandamine. Wood-based panels. Sampling, cutting and inspection. Part 1: Sampling and cutting of test pieces and expression of results.

17. ***Estonian Centre for Standardization, EVS EN 317, 2000: Puitlaastplaadid ja puitkiudplaadid. Pundumise määramine paksuses pärast leotamist. Particleboards and fibreboards. Determination of swelling in thickness after immersion in water.

18. ***Estonian is a Country of Forest - Statistics/Estonian Timber. https://estoniantimber.ee/statistics/ (Accessed Nov. 10, 2018).

19. ***Estonian Centre for Standardization, European Standard EVS EN 310: 2002. Puitplaadid. Paindeelastsusmooduli ja paindetugevuse määramine. Wood-based panels. Determination of modulus of elasticity in bending and of bending strength.

20. ***Estonian Centre for Standardization, EVS EN 322, 2002: Puitplaadid. Niiskussisalduse määramine. Woodbased panels - Determination of moisture content.

21. ***Estonian Centre for Standardization, EVS EN 325, 2012: Puitplaadid. Katsekehade mõõtmete määramine. Wood-based panels. Determination of dimensions of the pieces.

22. ***Manufacturing Process of Veneer and Plywood/Estonia Timber. https://estoniantimber.ee/best-practices/manufacturing-process-of-veneer-and-plywood/ (Accessed Nov. 10, 2018).

23. ***Finnish birch plywood - Metsä Wood. Retrieved from: www.metsawood.com/.../plywood/birch-plywood/.../Birch-plywood.asp (Accessed Nov. 10, 2018).

24. ***Finnish Forest Industries Fedration, 2002: Handbook of Finnish plywood. Kirjapaino Markprint Oy, Lahti, Finland. https://www.metsateollisuus.fi/uploads/ 2017/03/30041750/887.pdf (Accessed Nov. 10, 2018).

25. ***Plywood Manufacturing: Global Markets to 2022. Aug. 2018. Report 173 pages. BCC Research LLC. BCC Research LLC, 49 Walnut Park, Building 2, Wellesley, MA 02481, US.

26. ***Plywood Market: Global Demand Analysis \& Opportunity Outlook 2023. Report, ID: 261. April, 2019. Research Nester. 77 Water Street $8^{\text {th }}$ Floor, New York 10005, US.

27. ***Plywood Market: Strong Demand for MR Grade Plywood to Drive Growth: Global Industry Analysis 2013 2017 and Opportunity Assessment 2018 - 2028. 201811-12, 400 pages. Future Market Insights. $3^{\text {rd }}$ Floor, 207 Regent Street, London W1B 3HH, United Kingdom.

28. ***UN 2016. Food and agriculture organization of United Nations. Global forest products: facts and figures, 2016. http://www.fao.org/3/I7034EN/i7034en.pdf (Accessed Nov. 10, 2018).

\section{Corresponding address:}

\section{Prof. MIHKEL KIVISTE PhD}

Tallinn University of Technology (Taltech)

Tartu College

School of Engineering

Puiestee 78, 51008 Tartu, ESTONIA

e-mail: mihkel.kiviste@taltech.ee 